\title{
Conserved and Divergent Functions of the cAMP/PKA Signaling Pathway in Candida albicans and Candida tropicalis
}

\author{
Chi-Jan Lin ${ }^{(D)}$ and Ying-Lien Chen * (D) \\ Department of Plant Pathology and Microbiology, National Taiwan University, 10617 Taipei, Taiwan; \\ clin2@ntu.edu.tw \\ * Correspondence: ychen28@ntu.edu.tw; Tel.: +886-2-3366-1763; Fax: +886-2-2363-6490
}

Received: 27 April 2018; Accepted: 7 June 2018; Published: 8 June 2018

\begin{abstract}
Fungal species undergo many morphological transitions to adapt to changing environments, an important quality especially in fungal pathogens. For decades, Candida albicans has been one of the most prevalent human fungal pathogens, and recently, the prevalence of Candida tropicalis as a causative agent of candidiasis has increased. In C. albicans, the ability to switch between yeast and hyphal forms is thought to be a key virulence factor and is regulated by multiple signaling cascades_-including the cyclic adenosine monophosphate/protein kinase A (cAMP/PKA), calcineurin, high-osmolarity glycerol (HOG), and mitogen-activated protein kinases (MAPK) signaling pathways-upon receiving environmental cues. The cAMP/PKA signaling pathway also triggers white-opaque switching in C. albicans. However, studies on C. tropicalis morphogenesis are limited. In this minireview, we discuss the regulation of the yeast-hypha transition, virulence, and white-opaque switching through the cAMP/PKA pathway in the closely related species C. albicans and C. tropicalis.
\end{abstract}

Keywords: protein kinase A; cAMP; Candida albicans; C. tropicalis; hyphal growth; whiteopaque switching

\section{Introduction}

Candida species are common causative agents of superficial and invasive fungal infections worldwide [1,2]. Of the more than 150 Candida species, C. albicans is the most prevalent and has been responsible for $>60 \%$ of candidemia cases worldwide for decades [3]. Recently, the prevalence of non-albicans Candida species (NACs)—such as C. tropicalis, C. glabrata, and C. parapsilosis-in patients with candidiasis or candidemia has increased [4,5]. Among NACs, C. tropicalis is the first or second most commonly isolated species from patients with candidiasis, especially in tropical regions such as Brazil and Asia [6-10]. C. tropicalis is closely related to C. albicans based on genomic comparisons, but the natural habitats of these pathogens differ: C. albicans is a human commensal organism and is rarely found in the environment, whereas $C$. tropicalis is not only a commensal of the human oral cavity, but is also present in soil, compost, plants, beaches, and seawater in tropical or subtropical areas [11-14]. The ability of these species to occupy vastly different niches despite their genomic similarity may be due to distinct regulatory mechanisms upon receiving environmental cues, though knowledge of how this is accomplished is scant.

In order to propagate and cause disease, pathogens have developed several strategies to deal with the harsh conditions associated with survival within a host. In particular, morphological plasticity is an important tool for fungi to adapt to changing environments within a host. In C. albicans, the transition between yeast and filamentous (pseudohyphae and hyphae) forms as well as 
white-opaque switching have been observed and characterized. Cells that are locked in either yeast or hyphal forms have altered virulence, and white-opaque switching is associated with biofilm formation [15-25]. Environmental cues from different niches, such as the presence/absence of nutrients, serum, $\mathrm{CO}_{2}$, and high temperature, govern the morphological switch between different cell types in C. albicans $[16,18,26-33]$. These stimuli trigger various signaling transduction pathways, including the cyclic adenosine monophosphate/protein kinase A (cAMP/PKA), calcineurin, high-osmolarity glycerol (HOG), and mitogen-activated protein kinases (MAPK) pathways to promote or suppress morphological switching [15,16,34-37]. These morphological transitions also have been observed in $C$. tropicalis in various environmental conditions such as $\mathrm{CO}_{2}, \mathrm{pH}$, and $\mathrm{N}$-acetylglucosamine (GlcNAc) [38-43]. In this minireview, we focus on the involvement of the cAMP/PKA signaling pathway in the regulation of morphogenesis, virulence, and white-opaque switching in C. albicans and C. tropicalis.

\section{2. cAMP/PKA Signaling Pathway}

The cAMP/PKA signaling pathway is conserved in eukaryotic organisms and has been well studied due to its crucial roles in pathogenesis and development in human and plant pathogenic fungi [44-53]. In C. albicans, the PKA holoenzyme contains two "inactivate" catalytic subunits (Tpk1 and Tpk2), each bound to a homodimer regulatory subunit (Bcy1) (Figure 1). Environmental cues such as glucose, amino acids, and serum can trigger the cAMP/PKA signaling pathway by activating adenylyl cyclase (Cyr1) to convert ATP to cAMP [44,47]. As a secondary messenger, cAMP binds to the regulatory subunits of PKA (Bcy1) and induces a conformational change that leads to dissociation and activation of the PKA catalytic subunits. These catalytic subunits then activate downstream targets such as Efg1 in C. albicans and C. tropicalis or Flo8 in Saccharomyces cerevisiae via phosphorylation to trigger various transcriptional regulatory circuits [29,41,45,54-57].

In S. cerevisiae, the cAMP/PKA signaling pathway is involved in the regulation of cell growth and cellular differentiation [58-61]. The S. cerevisiae PKA catalytic subunits (Tpk1, Tpk2, and Tpk3) show distinct roles in pseudohyphal growth. ScTpk2 positively regulates pseudohyphal growth upon nitrogen starvation, while the other two catalytic subunits, (ScTpk1 and ScTpk3) negatively influence pseudohyphal growth [62,63]. In C. albicans, the cAMP/PKA pathway plays critical roles in growth, morphogenesis, white-opaque switching, and virulence in murine models of systemic infection $[16,18,64,65]$. Upstream of PKA, adenylyl cyclase (Cyr1/Cdc35) is involved in filamentation and virulence, but this protein is not required for cell viability [28]. In contrast, in early studies, the regulatory subunit Bcy1 and the catalytic subunits Tpk1 and Tpk2 are essential for viability. The $b c y 1 / b c y 1$ mutant is only viable in a tpk2/tpk2 mutant background, which has lower PKA activity compared with the wild type. Meanwhile, the conditional tpk1/tpk1 tpk2/tpk2 mutant can be acquired, but has severe growth defects $[66,67]$. Recent studies have shown that the catalytic and regulatory subunits of PKA are not all required for cell viability $[68,69]$. By obtaining a bcy1/bcy 1 mutant that exhibited severe growth defects, Ding et al. showed that Bcy1 controls filamentation in C. albicans [68]. Soon after, Cao et al. obtained a tpk1/tpk1 tpk2/tpk2 double deletion mutant that exhibited severe growth defects [69] - in line with previous studies in other pathogenic fungi such as Cryptococcus neoformans and Aspergillus fumigatus - showing that PKA is not essential for, but does regulate, fungal growth [49,70].

Although C. tropicalis is an emerging pathogen, studies related to its cAMP/PKA signaling pathway are limited. A pioneer study in C. tropicalis showed that Efg1, a transcription factor that is a potential downstream target of cAMP/PKA, is involved in the yeast-hypha transition, biofilm formation, and white-opaque switching [55]. Similarly, Efg1 also regulates morphogenesis and biofilm formation and is a downstream target of the cAMP/PKA pathway in C. albicans $[18,56,57,71,72]$. Hence, it appears that PKA has similar roles in C. tropicalis and C. albicans. The initial study of C. tropicalis PKA revealed that Tpk1 and Tpk2 have redundant functions in growth and filamentation, but the PKA catalytic null mutant was not viable. However, a few years later, two separate laboratories 
obtained tpk1/tpk1 tpk2/tpk2 mutants that exhibited severe defects in cell growth, filamentation, and white-opaque switching [43,73]. In addition, Zhang et al. showed that loss of the adenylyl cyclase CYR1 in C. tropicalis results in severe growth defects and reduced hyphal development [41]. Although the $C$. tropicalis adenylyl cyclase and PKA catalytic subunits have been identified and characterized, knowledge is limited on the functions of the regulatory subunit Bcy1 in growth and morphological transitions. Study of these PKA null mutants in C. albicans and C. tropicalis has facilitated the reevaluation of the global regulatory roles of the cAMP/PKA pathway.

A

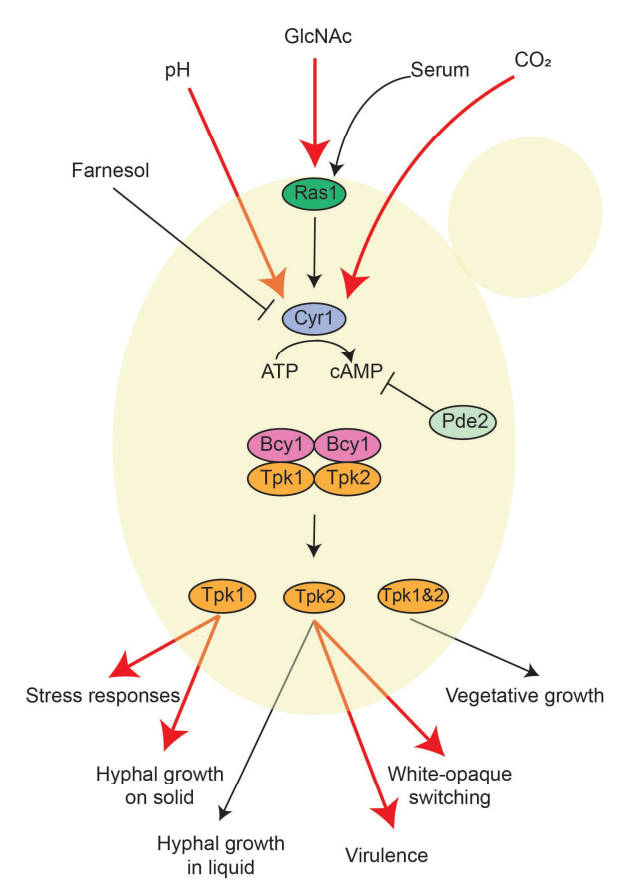

B

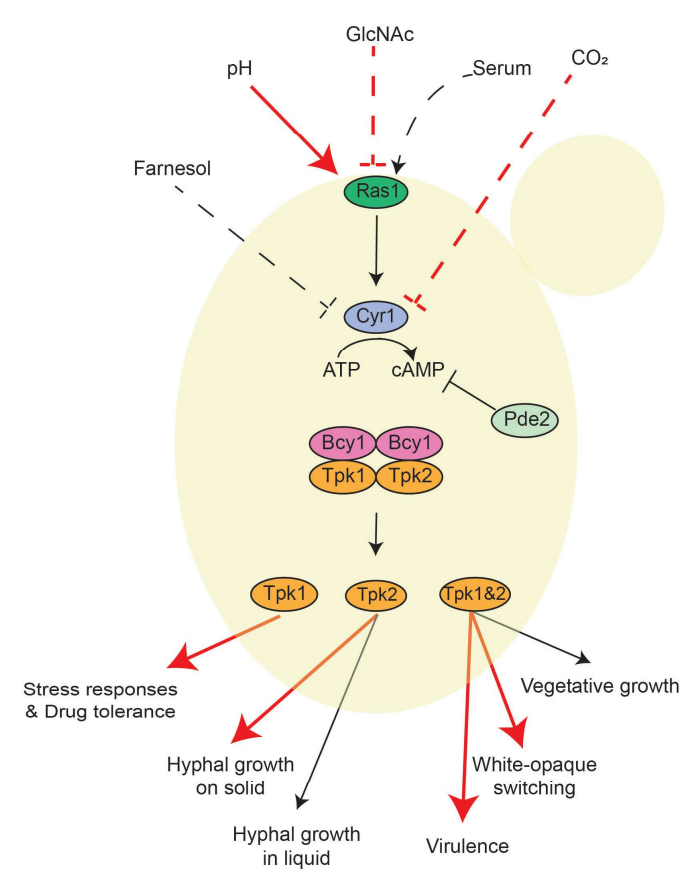

Figure 1. Regulatory models of the cyclic adenosine monophosphate/protein kinase A (cAMP/PKA) signaling pathway in C. albicans and C. tropicalis. Environmental cues activate CAMP/PKA in C. albicans (A) and C. tropicalis (B). Upon directly sensing environmental cues or being activated by Ras1, Cyr1 converts ATP to cAMP to bind the regulatory subunits of PKA (Bcy1) and liberate the catalytic subunits (Tpk1 and Tpk2). CaTpk1 is required for responding to stress (e.g., oxidative, osmotic, and thermal stressors), while CtTpk1 controls cell wall integrity and drug tolerance. In C. albicans, Tpk1 contributes to hyphal growth on solid media and Tpk2 is involved in hyphal growth in liquid media. In contrast, only Tpk2 contributes to hyphal growth on solid or in liquid media in C. tropicalis. In both species, Tpk1 and Tpk2 have redundant roles in vegetative growth. Furthermore, CtTpk1 and CtTpk2 share redundant functions in white-opaque switching and virulence, but in C. albicans, these two phenotypes are only controlled by Tpk2. GlcNAc induces both hyphal growth and white-opaque switching in C. albicans. In contrast, GlcNAc inhibits hyphal growth but promotes white-opaque switching in C. tropicalis. $\mathrm{CO}_{2}$ induces white-opaque switching in C. albicans, but inhibits the same transition in C. tropicalis. Environmental pH regulates hyphal growth via Cyr1 in C. albicans. In contrast, environmental $\mathrm{pH}$ controls white-opaque switching through Ras1-cAMP/PKA in C. tropicalis. Red lines and arrows indicate differences and dash lines represent these interactions have not been characterized between C. albicans and C. tropicalis.

\section{1. $c A M P / P K A$ Regulation of the Yeast-Hypha Transition and Virulence}

cAMP is required to trigger the activation of the PKA pathway in response to various environmental stimuli, including GlcNAc, serum, amino acids, and $\mathrm{CO}_{2}$. Intracellular cAMP levels are tightly regulated by adenylyl cyclase (Cyr1) and phosphodiesterase (Pde2), which produce and degrade 
cAMP, respectively (Figure 1). In C. albicans, Cyr1 (which is not an essential gene) regulates hyphal growth induced by serum, $\mathrm{CO}_{2}$, or bacterial peptidoglycan $[28,31,74]$, while the phosphodiesterase Pde2 plays a role in limiting intracellular cAMP levels. Loss of PDE2 results in reduced hyphal growth and attenuated virulence in a murine model of systemic infection $[75,76]$. The $C a C Y R 1$ and CaPDE2 homologs are also involved in filamentation in C. tropicalis: The loss of CtCYR1 and CtPDE2 results in attenuated and enhanced filamentation, respectively [41]. Interestingly, Cyr1, but not Pde2, was demonstrated to impact cell growth (Table 1) [41].

Table 1. Conserved and divergent functions of the cAMP/PKA signaling pathway in C. albicans and C. tropicalis.

\begin{tabular}{|c|c|c|c|c|c|c|c|c|c|c|c|c|}
\hline \multirow{2}{*}{\begin{tabular}{|ll} 
Phenotypes & Genotypes \\
\end{tabular}} & \multicolumn{2}{|c|}{ cyr1/cyr1 } & \multicolumn{2}{|c|}{$b c y 1 / b c y 1$} & \multicolumn{2}{|c|}{$t p k 1 / t p k 1$} & \multicolumn{2}{|c|}{$t p k 2 / t p k 2$} & \multicolumn{2}{|c|}{$t p k 1 / t p k 1$ tpk2/tpk2 } & \multicolumn{2}{|c|}{$p d e 2 / p d e 2$} \\
\hline & $\mathrm{Ca}$ & $\mathrm{Ct}$ & $\mathrm{Ca}$ & $\mathrm{Ct}$ & $\mathrm{Ca}$ & $\mathrm{Ct}$ & $\mathrm{Ca}$ & $\mathrm{Ct}$ & $\mathrm{Ca}$ & $\mathrm{Ct}$ & $\mathrm{Ca}$ & $\mathrm{Ct}$ \\
\hline Vegetative growth & A & A & A & - & WT & WT & WT & WT & A & $\mathrm{A}$ & $\mathrm{A}$ & WT \\
\hline $\begin{array}{c}\text { Hyphal } \\
\text { development }\end{array}$ & A & A & $\mathrm{E} / \mathrm{A}$ & - & WT & WT & WT/A & WT/E & A & $\mathrm{A}$ & $\mathrm{A}$ & E \\
\hline $\begin{array}{l}\text { White-opaque } \\
\text { switch }\end{array}$ & A & $\mathrm{A}$ & E & - & WT & WT & A & WT & A & A & $\mathrm{E}$ & E \\
\hline Virulence & A & - & - & - & WT & WT & A & WT & - & A & $\mathrm{A}$ & - \\
\hline
\end{tabular}

A, attenuated; Ca, C. albicans; Ct, C. tropicalis; E, enhanced; WT, similar to wild type; - not determined.

In C. albicans, Tpk1 and Tpk2 have redundant roles in growth and dimorphic switching, but each has distinct roles in hyphal development in various filamentation-inducing conditions $[67,72,77,78]$. CaTpk1 contributes to filamentation on solid medium, while CaTpk2 is involved in hyphal growth in liquid medium $[67,72,78,79]$. In addition, the tpk2/tpk2 mutant, but not the tpk1/tpk1 mutant, exhibited reduced virulence in murine model of systemic infection [72]; interestingly, the C. albicans tpk1/tpk1 $t p k 2 / p t k 2$ double deletion mutant showed no hyphal growth in the various tested conditions, including solid and liquid Spider medium and Lee's medium supplemented with glucose or GlcNAc as well as YPD with serum in liquid [69]. The virulence of the tpk1/tpk1 tpk2/tpk2 mutant has not been characterized, but it is predicted to have attenuated or abolished virulence due to its severe defects in cell growth, hyphal growth, and white-opaque switching [69].

Similar to the C. albicans tpk1/tpk1 tpk2/tpk2 double deletion mutant, the bcy1/bcy1 mutant is not viable due to its high PKA activity in early studies. However, the $b c y 1 / b c y 1$ mutant was obtained in a tpk2/tpk2 mutant background, which has reduced PKA activity, and showed defects in hyphal growth [66]. Recently, Ding et al. obtained a bcy1/bcy1 null mutant in a C. albicans SN152 background that had two distinct phenotypes: smooth and filamentous [68]. Smooth $b c y 1 / b c y 1$ cells had defects in hyphal growth, while the filamentous $b c y 1 / b c y 1$ mutant exhibited hyphal growth indistinguishable from that of the wild type. Interestingly, the byc1/bcy1 mutant was able to switch between these two phenotypes on YPD plates and in liquid SD medium, but had a preference for the filamentous phenotype under both conditions [68].

The first study of PKA in C. tropicalis was published in 2016 and suggested that Tpk1 and Tpk2 have redundant roles in filamentation and cell growth [41]. A year later, the same group reported severe defects in cell growth and white-opaque switching in the tpk1/tpk1 tpk2/tpk2 double mutant, but did not characterize the impact on filamentation [43]. In 2018, Lin et al. demonstrated the viability of the C. tropicalis tpk1/tpk1 tpk2/tpk2 mutant despite severe defects in cell growth, filamentation, and virulence in a murine model of systemic infection [73]. Surprisingly, the C. tropicalis tpk1/tpk1 and tpk2/tpk2 mutants showed virulence similar to the wild type in murine model of systemic infection. In addition to the redundant roles in cell growth and virulence, this group also found that Tpk1 and Tpk2 have distinct roles. For example, Tpk1 contributes to stress responses and antifungal drug tolerance, while Tpk2 plays a key role in filamentation, flocculation, and biofilm formation in C. tropicalis [73]. While CaTpk2 is required for virulence, CtTpk2 is not, suggesting divergent roles of Tpk2 in virulence between C. albicans and C. tropicalis (Table 1). 


\subsection{Regulation of White-Opaque Switching through the cAMP/PKA Pathway}

In addition to transitioning between yeast and hyphal growth, C. albicans and C. tropicalis can undergo white-opaque switching-a heritable morphological change [40,43,80-83]. White cells (a, $\alpha$, or a $/ \alpha$ ) form white, shiny, and smooth colonies on solid media. In inducing conditions such as GlcNAc or high $\mathrm{CO}_{2}$ concentrations, white cells transition to opaque cells and colonies that appear elongated, flat, and gray on solid media [17,84-86]. Similarly, C. tropicalis white cell colonies exhibit a rounded, smooth surface, while colonies of opaque cells have an elongated, pimpled surface $[40,82]$. However, slight differences have been noted between the opaque cells of $C$. albicans and C. tropicalis: C. tropicalis opaque cells cannot be stained with phloxine B whereas C. albicans opaque cells can, and $C$. tropicalis opaque cells are stable at high temperature $\left(37^{\circ} \mathrm{C}\right)$ whereas $C$. albicans opaque cells are not [82]. In addition to the differences noted above, high $\mathrm{CO}_{2}$ concentrations (5 20\%) induce white-opaque switching and stabilize opaque cells at $37^{\circ} \mathrm{C}$ in C. albicans, but inhibit the white-opaque transition in C. tropicalis $[43,86,87]$.

Several studies have shown that the C. albicans cAMP/PKA pathway is highly involved in white-opaque switching $[68,69,87,88]$. The $t p k 1 / t p k 1$ or $t p k 2 / t p k 2$ mutant in C. albicans has a similar rate of white-opaque switching compared to the wild type in various culture conditions [69], but loss of CYR1 results in low intracellular cAMP concentration, and a tpk1/tpk1 tpk2/tpk2 mutant without obvious PKA activity showed severe defects in white-opaque switching $[69,87,88]$. In contrast, pde2/pde2 knockout, bcy1/bcy1 knockout, or TPK2 overexpression results in cAMP/PKA pathway activation, thus promoting the white-opaque transition (Table 1) [68,69].

Similarly, the cAMP/PKA pathway plays an important role in white-opaque switching in C. tropicalis. Zheng et al. showed that loss of either TPK1 or TPK2 in C. tropicalis has no effect on white-opaque switching. However, activation of the CAMP/PKA pathway by PDE2 deletion results in enhanced white-opaque switching, and deactivation of the cAMP/PKA pathway in a cyr1/cyr1 mutant or PKA null mutant results in reduced or abolished white-opaque switching, respectively (Table 1) [43].

Although the cAMP/PKA pathway is involved in white-opaque switching in C. albicans and C. tropicalis, it is activated by different conditions in these close relatives. In C. albicans, cAMP levels are high (and thus promote white-opaque switching) in acidic or high $\mathrm{CO}_{2}$ conditions, whereas $C$. tropicalis cAMP levels are higher in alkaline and normal air conditions $[43,69]$. This difference might be due to the natural habitats of these fungal pathogens: C. albicans is a commensal that lives in different niches within humans with relatively high $\mathrm{CO}_{2}$ concentrations, while the environmental microorganism C. tropicalis is well adapted to normal air.

\section{Conclusions}

Although C. albicans and C. tropicalis are close relatives, their different natural habitats have shaped their regulatory systems via conserved signaling pathways (such as the cAMP/PKA pathway), which can facilitate the establishment of infection. In C. albicans and C. tropicalis, the CAMP/PKA singling pathway regulates the yeast-hypha transition, virulence, and white-opaque switching. In general, the components of the CAMP/PKA signaling pathway in the two species have similar roles in vegetative growth, hyphal development, and white-opaque switching. Interestingly, the catalytic subunit Tpk2 shows distinct roles in virulence between the species: CaTpk2, but not CtTpk2, is required for virulence in a murine model of systemic infection. Furthermore, different conditions induce or suppress the yeast-hypha transition and white-opaque switching in these two fungal pathogens, suggesting that cAMP/PKA might respond to different environmental cues. In addition to morphogenesis, the $C$. albicans CAMP/PKA pathway has been shown to regulate glycogen synthesis, energy metabolism, and mitochondrial activity [79,89]. Inhibition of mitochondrial activity resulted in reduced Ras1 and Cyr1 activity and consequently attenuated filamentation [89]. In addition, other proteins, such as Hsp90 and its co-activator Sgt1, regulate morphogenesis and drug tolerance in C. albicans $[30,90]$, and small chemical compounds have also been found to control its morphogenesis 
via the cAMP/PKA pathway [91-93]. Furthermore, as the cAMP/PKA pathway is conserved in eukaryotic cells and regulates virulence in C. albicans and C. tropicalis, this pathway might be a promising target for antifungal drug development. A similar approach in the calcineurin pathway [94] has shown that calcineurin inhibitors exhibit antifungal activity alone or synergistically with other existing drugs, such as fluconazole, against C. albicans and C. neoformans $[95,96]$. Although the cAMP/PKA pathway is well characterized in C. albicans, knowledge of this important pathway in C. tropicalis is limited. Comparative studies on the roles of $\mathrm{Hsp} 90$ and small molecules in morphogenesis and virulence and the roles of CAMP/PKA in metabolic adaptation in C. tropicalis will contribute to the understanding of how these fungal pathogens utilize the CAMP/PKA pathway to cause human infections.

Author Contributions: C.-J.L. and Y.-L.C. jointly wrote and edited this manuscript.

Funding: Ministry of Science \& Technology (MOST), Taiwan; MOST 104-2320-B-002-063-MY3 and 106-2923-B-002001-MY3.

Acknowledgments: This work was financially supported by grants MOST 104-2320-B-002-063-MY3 and 106-2923-B-002-001-MY3. The authors thank Cecelia Wall for language editing.

Conflicts of Interest: The authors declare no conflicts of interest.

\section{References}

1. Brown, G.D.; Denning, D.W.; Gow, N.A.; Levitz, S.M.; Netea, M.G.; White, T.C. Hidden killers: Human fungal infections. Sci. Transl. Med. 2012, 4, 165rv113. [CrossRef] [PubMed]

2. Antinori, S.; Milazzo, L.; Sollima, S.; Galli, M.; Corbellino, M. Candidemia and invasive candidiasis in adults: A narrative review. Eur. J. Intern. Med. 2016, 34, 21-28. [CrossRef] [PubMed]

3. Guinea, J. Global trends in the distribution of Candida species causing candidemia. Clin. Microbiol. Infect. 2014, 20, 5-10. [CrossRef] [PubMed]

4. Pfaller, M.; Diekema, D. Epidemiology of invasive candidiasis: A persistent public health problem. Clin. Microbiol. Rev. 2007, 20, 133-163. [CrossRef] [PubMed]

5. Andes, D.R.; Safdar, N.; Baddley, J.W.; Playford, G.; Reboli, A.C.; Rex, J.H.; Sobel, J.D.; Pappas, P.G.; Kullberg, B.J. Impact of treatment strategy on outcomes in patients with candidemia and other forms of invasive candidiasis: A patient-level quantitative review of randomized trials. Clin. Infect. Dis. 2012, 54, 1110-1122. [CrossRef] [PubMed]

6. Nucci, M.; Colombo, A.L. Candidemia due to Candida tropicalis: Clinical, epidemiologic, and microbiologic characteristics of 188 episodes occurring in tertiary care hospitals. Diagn. Microbiol. Infect. Dis. 2007, 58, 77-82. [CrossRef] [PubMed]

7. Hsueh, P.R.; Graybill, J.R.; Playford, E.G.; Watcharananan, S.P.; Oh, M.D.; Ja'alam, K.; Huang, S.; Nangia, V.; Kurup, A.; Padiglione, A.A. Consensus statement on the management of invasive candidiasis in Intensive Care Units in the Asia-Pacific Region. Int. J. Antimicrob. Agents 2009, 34, 205-209. [CrossRef] [PubMed]

8. Tan, B.H.; Chakrabarti, A.; Li, R.Y.; Patel, A.K.; Watcharananan, S.P.; Liu, Z.; Chindamporn, A.; Tan, A.L.; Sun, P.L.; Wu, U.I.; et al. Incidence and species distribution of candidaemia in Asia: A laboratory-based surveillance study. Clin. Microbiol. Infect. 2015, 21, 946-953. [CrossRef] [PubMed]

9. Rodrigues, C.F.; Rodrigues, M.E.; Silva, S.; Henriques, M. Candida glabrata Biofilms: How Far Have We Come? J. Fungi 2017, 3, 11. [CrossRef] [PubMed]

10. Colombo, A.L.; Guimaraes, T.; Silva, L.R.; de Almeida Monfardini, L.P.; Cunha, A.K.; Rady, P.; Alves, T.; Rosas, R.C. Prospective observational study of candidemia in Sao Paulo, Brazil: Incidence rate, epidemiology, and predictors of mortality. Infect. Control Hosp. Epidemiol. 2007, 28, 570-576. [CrossRef] [PubMed]

11. Zuza-Alves, D.L.; de Medeiros, S.S.; de Souza, L.B.; Silva-Rocha, W.P.; Francisco, E.C.; de Araujo, M.C.; Lima-Neto, R.G.; Neves, R.P.; Melo, A.S.; Chaves, G.M. Evaluation of virulence factors in vitro, resistance to osmotic stress and antifungal susceptibility of Candida tropicalis isolated from the coastal environment of Northeast Brazil. Front. Microbiol. 2016, 7, 1783. [CrossRef] [PubMed]

12. Butler, G.; Rasmussen, M.D.; Lin, M.F.; Santos, M.A.; Sakthikumar, S.; Munro, C.A.; Rheinbay, E.; Grabherr, M.; Forche, A.; Reedy, J.L.; et al. Evolution of pathogenicity and sexual reproduction in eight Candida genomes. Nature 2009, 459, 657-662. [CrossRef] [PubMed] 
13. Yang, Y.L.; Lin, C.C.; Chang, T.P.; Lauderdale, T.L.; Chen, H.T.; Lee, C.F.; Hsieh, C.W.; Chen, P.C.; Lo, H.J. Comparison of human and soil Candida tropicalis isolates with reduced susceptibility to fluconazole. PLoS ONE 2012, 7, e34609. [CrossRef] [PubMed]

14. De Barros, P.P.; Rossoni, R.D.; Freire, F.; Ribeiro, F.C.; Lopes, L.; Junqueira, J.C.; Jorge, A.O.C. Candida tropicalis affects the virulence profile of Candida albicans: An in vitro and in vivo study. Pathog. Dis. 2018, 76. [CrossRef] [PubMed]

15. Gow, N.A.; van de Veerdonk, F.L.; Brown, A.J.; Netea, M.G. Candida albicans morphogenesis and host defence: Discriminating invasion from colonization. Nat. Rev. Microbiol. 2012, 10, 112-122. [CrossRef] [PubMed]

16. Biswas, S.; Van Dijck, P.; Datta, A. Environmental sensing and signal transduction pathways regulating morphopathogenic determinants of Candida albicans. Microbiol. Mol. Biol. Rev. 2007, 71, 348-376. [CrossRef] [PubMed]

17. Huang, G. Regulation of phenotypic transitions in the fungal pathogen Candida albicans. Virulence 2012, 3, 251-261. [CrossRef] [PubMed]

18. Noble, S.M.; Gianetti, B.A.; Witchley, J.N. Candida albicans cell-type switching and functional plasticity in the mammalian host. Nat. Rev. Microbiol. 2017, 15, 96-108. [CrossRef] [PubMed]

19. Slutsky, B.; Buffo, J.; Soll, D.R. High-frequency switching of colony morphology in Candida albicans. Science 1985, 230, 666-669. [CrossRef] [PubMed]

20. Daniels, K.J.; Srikantha, T.; Lockhart, S.R.; Pujol, C.; Soll, D.R. Opaque cells signal white cells to form biofilms in Candida albicans. EMBO J. 2006, 25, 2240-2252. [CrossRef] [PubMed]

21. Lo, H.J.; Kohler, J.R.; DiDomenico, B.; Loebenberg, D.; Cacciapuoti, A.; Fink, G.R. Nonfilamentous C. albicans mutants are avirulent. Cell 1997, 90, 939-949. [CrossRef]

22. Si, H.; Hernday, A.D.; Hirakawa, M.P.; Johnson, A.D.; Bennett, R.J. Candida albicans white and opaque cells undergo distinct programs of filamentous growth. PLoS Pathog. 2013, 9, e1003210. [CrossRef] [PubMed]

23. Pujol, C.; Daniels, K.J.; Soll, D.R. Comparison of Switching and Biofilm Formation between MTL-Homozygous Strains of Candida albicans and Candida dubliniensis. Eukaryot. Cell 2015, 14, 1186-1202. [CrossRef] [PubMed]

24. Murad, A.M.; Leng, P.; Straffon, M.; Wishart, J.; Macaskill, S.; MacCallum, D.; Schnell, N.; Talibi, D.; Marechal, D.; Tekaia, F.; et al. NRG1 represses yeast-hypha morphogenesis and hypha-specific gene expression in Candida albicans. EMBO J. 2001, 20, 4742-4752. [CrossRef] [PubMed]

25. Braun, B.R.; Johnson, A.D. Control of filament formation in Candida albicans by the transcriptional repressor TUP1. Science 1997, 277, 105-109. [CrossRef] [PubMed]

26. Whiteway, M.; Bachewich, C. Morphogenesis in Candida albicans. Annu. Rev. Microbiol. 2007, 61, 529-553. [CrossRef] [PubMed]

27. Feng, Q.; Summers, E.; Guo, B.; Fink, G. Ras signaling is required for serum-induced hyphal differentiation in Candida albicans. J. Bacteriol. 1999, 181, 6339-6346. [PubMed]

28. Rocha, C.R.; Schroppel, K.; Harcus, D.; Marcil, A.; Dignard, D.; Taylor, B.N.; Thomas, D.Y.; Whiteway, M.; Leberer, E. Signaling through adenylyl cyclase is essential for hyphal growth and virulence in the pathogenic fungus Candida albicans. Mol. Biol. Cell 2001, 12, 3631-3643. [CrossRef] [PubMed]

29. Cao, F.; Lane, S.; Raniga, P.P.; Lu, Y.; Zhou, Z.; Ramon, K.; Chen, J.; Liu, H. The Flo8 transcription factor is essential for hyphal development and virulence in Candida albicans. Mol. Biol. Cell 2006, 17, $295-307$. [CrossRef] [PubMed]

30. Shapiro, R.S.; Uppuluri, P.; Zaas, A.K.; Collins, C.; Senn, H.; Perfect, J.R.; Heitman, J.; Cowen, L.E. Hsp90 orchestrates temperature-dependent Candida albicans morphogenesis via Ras1-PKA signaling. Curr. Biol. 2009, 19, 621-629. [CrossRef] [PubMed]

31. Klengel, T.; Liang, W.J.; Chaloupka, J.; Ruoff, C.; Schroppel, K.; Naglik, J.R.; Eckert, S.E.; Mogensen, E.G.; Haynes, K.; Tuite, M.F.; et al. Fungal adenylyl cyclase integrates $\mathrm{CO}_{2}$ sensing with cAMP signaling and virulence. Curr. Biol. 2005, 15, 2021-2026. [CrossRef] [PubMed]

32. Cassone, A.; Sullivan, P.A.; Shepherd, M.G. N-acetyl-D-glucosamine-induced morphogenesis in Candida albicans. Microbiologica 1985, 8, 85-99. [PubMed]

33. Hollomon, J.M.; Grahl, N.; Willger, S.D.; Koeppen, K.; Hogan, D.A. Global Role of Cyclic AMP Signaling in pH-Dependent Responses in Candida albicans. mSphere 2016, 1, e00283-16. [CrossRef] [PubMed] 
34. Sanglard, D.; Ischer, F.; Marchetti, O.; Entenza, J.; Bille, J. Calcineurin A of Candida albicans: Involvement in antifungal tolerance, cell morphogenesis and virulence. Mol. Microbiol. 2003, 48, 959-976. [CrossRef] [PubMed]

35. Kohler, J.R.; Fink, G.R. Candida albicans strains heterozygous and homozygous for mutations in mitogen-activated protein kinase signaling components have defects in Hyphal development. Proc. Natl. Acad. Sci. USA 1996, 93, 13223-13228. [CrossRef] [PubMed]

36. Leberer, E.; Harcus, D.; Broadbent, I.D.; Clark, K.L.; Dignard, D.; Ziegelbauer, K.; Schmidt, A.; Gow, N.A.; Brown, A.J.; Thomas, D.Y. Signal transduction through homologs of the Ste20p and Ste7p protein kinases can trigger hyphal formation in the pathogenic fungus Candida albicans. Proc. Natl. Acad. Sci. USA 1996, 93, 13217-13222. [CrossRef] [PubMed]

37. Csank, C.; Schroppel, K.; Leberer, E.; Harcus, D.; Mohamed, O.; Meloche, S.; Thomas, D.Y.; Whiteway, M. Roles of the Candida albicans mitogen-activated protein kinase homolog, Cek1p, in hyphal development and systemic candidiasis. Infect. Immun. 1998, 66, 2713-2721. [PubMed]

38. Silva, S.; Negri, M.; Henriques, M.; Oliveira, R.; Williams, D.W.; Azeredo, J. Candida glabrata, Candida parapsilosis and Candida tropicalis: Biology, epidemiology, pathogenicity and antifungal resistance. FEMS Microbiol. Rev. 2012, 36, 288-305. [CrossRef] [PubMed]

39. Negri, M.; Silva, S.; Henriques, M.; Oliveira, R. Insights into Candida tropicalis nosocomial infections and virulence factors. Eur. J. Clin. Microbiol. Infect. Dis. 2012, 31, 1399-1412. [CrossRef] [PubMed]

40. Xie, J.; Du, H.; Guan, G.; Tong, Y.; Kourkoumpetis, T.K.; Zhang, L.; Bai, F.Y.; Huang, G. N-acetylglucosamine induces white-to-opaque switching and mating in Candida tropicalis, providing new insights into adaptation and fungal sexual evolution. Eukaryot. Cell 2012, 11, 773-782. [CrossRef] [PubMed]

41. Zhang, Q.; Tao, L.; Guan, G.; Yue, H.; Liang, W.; Cao, C.; Dai, Y.; Huang, G. Regulation of filamentation in the human fungal pathogen Candida tropicalis. Mol. Microbiol. 2016, 99, 528-545. [CrossRef] [PubMed]

42. Chen, Y.L.; Yu, S.J.; Huang, H.Y.; Chang, Y.L.; Lehman, V.N.; Silao, F.G.; Bigol, U.G.; Bungay, A.A.; Averette, A.; Heitman, J. Calcineurin controls hyphal growth, virulence, and drug tolerance of Candida tropicalis. Eukaryot. Cell 2014, 13, 844-854. [CrossRef] [PubMed]

43. Zheng, Q.; Zhang, Q.; Bing, J.; Ding, X.; Huang, G. Environmental and genetic regulation of white-opaque switching in Candida tropicalis. Mol. Microbiol. 2017. [CrossRef] [PubMed]

44. Fuller, K.K.; Rhodes, J.C. Protein kinase A and fungal virulence: A sinister side to a conserved nutrient sensing pathway. Virulence 2012, 3, 109-121. [CrossRef] [PubMed]

45. Hogan, D.A.; Sundstrom, P. The Ras/cAMP/PKA signaling pathway and virulence in Candida albicans. Future Microbiol. 2009, 4, 1263-1270. [CrossRef] [PubMed]

46. Kozubowski, L.; Lee, S.C.; Heitman, J. Signalling pathways in the pathogenesis of Cryptococcus. Cell. Microbiol. 2009, 11, 370-380. [CrossRef] [PubMed]

47. McDonough, K.A.; Rodriguez, A. The myriad roles of cyclic AMP in microbial pathogens: From signal to sword. Nat. Rev. Microbiol. 2012, 10, 27-38. [CrossRef] [PubMed]

48. Liebmann, B.; Müller, M.; Braun, A.; Brakhage, A.A. The cyclic AMP-dependent protein kinase a network regulates development and virulence in Aspergillus fumigatus. Infect. Immun. 2004, 72, 5193-5203. [CrossRef] [PubMed]

49. D’Souza, C.A.; Alspaugh, J.A.; Yue, C.; Harashima, T.; Cox, G.M.; Perfect, J.R.; Heitman, J. Cyclic AMP-dependent protein kinase controls virulence of the fungal pathogen Cryptococcus neoformans. Mol. Cell. Biol. 2001, 21, 3179-3191. [CrossRef] [PubMed]

50. Choi, J.; Vogl, A.W.; Kronstad, J.W. Regulated expression of cyclic AMP-dependent protein kinase A reveals an influence on cell size and the secretion of virulence factors in Cryptococcus neoformans. Mol. Microbiol. 2012, 85, 700-715. [CrossRef] [PubMed]

51. Hu, S.; Zhou, X.; Gu, X.; Cao, S.; Wang, C.; Xu, J.R. The cAMP-PKA pathway regulates growth, sexual and asexual differentiation, and pathogenesis in Fusarium graminearum. Mol. Plant Microbe Interact. 2014, 27, 557-566. [CrossRef] [PubMed]

52. Adachi, K.; Hamer, J.E. Divergent cAMP signaling pathways regulate growth and pathogenesis in the rice blast fungus Magnaporthe grisea. Plant Cell 1998, 10, 1361-1374. [CrossRef] [PubMed]

53. Li, Y.; Zhang, X.; Hu, S.; Liu, H.; Xu, J.R. PKA activity is essential for relieving the suppression of hyphal growth and appressorium formation by MoSfl1 in Magnaporthe oryzae. PLoS Genet. 2017, 13, e1006954. [CrossRef] [PubMed] 
54. Brückner, S.; Mösch, H.U. Choosing the right lifestyle: Adhesion and development in Saccharomyces cerevisiae. FEMS Microbiol. Rev. 2012, 36, 25-58. [CrossRef] [PubMed]

55. Mancera, E.; Porman, A.M.; Cuomo, C.A.; Bennett, R.J.; Johnson, A.D. Finding a Missing Gene: EFG1 Regulates Morphogenesis in Candida tropicalis. G3 Genes Genomes Genet. 2015, 5, 849-856. [CrossRef] [PubMed]

56. Bockmühl, D.P.; Ernst, J.F. A potential phosphorylation site for an A-type kinase in the Efg1 regulator protein contributes to hyphal morphogenesis of Candida albicans. Genetics 2001, 157, 1523-1530. [PubMed]

57. Saputo, S.; Kumar, A.; Krysan, D.J. Efg1 directly regulates ACE2 expression to mediate cross talk between the cAMP/PKA and RAM pathways during Candida albicans morphogenesis. Eukaryot. Cell 2014, 13, 1169-1180. [CrossRef] [PubMed]

58. Thevelein, J.M.; de Winde, J.H. Novel sensing mechanisms and targets for the cAMP-protein kinase A pathway in the yeast Saccharomyces cerevisiae. Mol. Microbiol. 1999, 33, 904-918. [CrossRef] [PubMed]

59. Wang, L.; Renault, G.; Garreau, H.; Jacquet, M. Stress induces depletion of Cdc25p and decreases the cAMP producing capability in Saccharomyces cerevisiae. Microbiology 2004, 150, 3383-3391. [CrossRef] [PubMed]

60. Cullen, P.J.; Sprague, G.F., Jr. Glucose depletion causes haploid invasive growth in yeast. Proc. Natl. Acad. Sci. USA 2000, 97, 13619-13624. [CrossRef] [PubMed]

61. Cullen, P.J.; Sprague, G.F., Jr. The regulation of filamentous growth in yeast. Genetics 2012, 190, $23-49$. [CrossRef] [PubMed]

62. Pan, X.; Heitman, J. Cyclic AMP-dependent protein kinase regulates pseudohyphal differentiation in Saccharomyces cerevisiae. Mol. Cell. Biol. 1999, 19, 4874-4887. [CrossRef] [PubMed]

63. Robertson, L.S.; Fink, G.R. The three yeast A kinases have specific signaling functions in pseudohyphal growth. Proc. Natl. Acad. Sci. USA 1998, 95, 13783-13787. [CrossRef] [PubMed]

64. Inglis, D.O.; Sherlock, G. Ras signaling gets fine-tuned: Regulation of multiple pathogenic traits of Candida albicans. Eukaryot. Cell 2013, 12, 1316-1325. [CrossRef] [PubMed]

65. Mayer, F.L.; Wilson, D.; Hube, B. Candida albicans pathogenicity mechanisms. Virulence 2013, 4, 119-128. [CrossRef] [PubMed]

66. Cassola, A.; Parrot, M.; Silberstein, S.; Magee, B.B.; Passeron, S.; Giasson, L.; Cantore, M.L. Candida albicans lacking the gene encoding the regulatory subunit of protein kinase A displays a defect in hyphal formation and an altered localization of the catalytic subunit. Eukaryot. Cell 2004, 3, 190-199. [CrossRef] [PubMed]

67. Bockmühl, D.P.; Krishnamurthy, S.; Gerads, M.; Sonneborn, A.; Ernst, J.F. Distinct and redundant roles of the two protein kinase A isoforms Tpk1p and Tpk2p in morphogenesis and growth of Candida albicans. Mol. Microbiol. 2001, 42, 1243-1257. [CrossRef] [PubMed]

68. Ding, X.; Cao, C.; Zheng, Q.; Huang, G. The Regulatory Subunit of Protein Kinase A (Bcy1) in Candida albicans Plays Critical Roles in Filamentation and White-Opaque Switching but Is Not Essential for Cell Growth. Front. Microbiol. 2016, 7, 2127. [CrossRef] [PubMed]

69. Cao, C.; Wu, M.; Bing, J.; Tao, L.; Ding, X.; Liu, X.; Huang, G. Global regulatory roles of the cAMP/PKA pathway revealed by phenotypic, transcriptomic and phosphoproteomic analyses in a null mutant of the PKA catalytic subunit in Candida albicans. Mol. Microbiol. 2017, 105, 46-64. [CrossRef] [PubMed]

70. Fuller, K.K.; Richie, D.L.; Feng, X.; Krishnan, K.; Stephens, T.J.; Wikenheiser-Brokamp, K.A.; Askew, D.S.; Rhodes, J.C. Divergent Protein Kinase A isoforms co-ordinately regulate conidial germination, carbohydrate metabolism and virulence in Aspergillus fumigatus. Mol. Microbiol. 2011, 79, 1045-1062. [CrossRef] [PubMed]

71. Sonneborn, A.; Bockmuhl, D.P.; Ernst, J.F. Chlamydospore formation in Candida albicans requires the Efg1p morphogenetic regulator. Infect. Immun. 1999, 67, 5514-5517. [PubMed]

72. Sonneborn, A.; Bockmühl, D.P.; Gerads, M.; Kurpanek, K.; Sanglard, D.; Ernst, J.F. Protein kinase A encoded by TPK2 regulates dimorphism of Candida albicans. Mol. Microbiol. 2000, 35, 386-396. [CrossRef] [PubMed]

73. Lin, C.J.; Wu, C.Y.; Yu, S.J.; Chen, Y.L. Protein kinase A governs growth and virulence in Candida tropicalis. Virulence 2018, 9, 331-347. [CrossRef] [PubMed]

74. Xu, X.L.; Lee, R.T.; Fang, H.M.; Wang, Y.M.; Li, R.; Zou, H.; Zhu, Y.; Wang, Y. Bacterial peptidoglycan triggers Candida albicans hyphal growth by directly activating the adenylyl cyclase Cyr1p. Cell Host Microbe 2008, 4, 28-39. [CrossRef] [PubMed]

75. Wilson, D.; Tutulan-Cunita, A.; Jung, W.; Hauser, N.C.; Hernandez, R.; Williamson, T.; Piekarska, K.; Rupp, S.; Young, T.; Stateva, L. Deletion of the high-affinity cAMP phosphodiesterase encoded by PDE2 affects stress responses and virulence in Candida albicans. Mol. Microbiol. 2007, 65, 841-856. [CrossRef] [PubMed] 
76. Jung, W.H.; Stateva, L.I. The cAMP phosphodiesterase encoded by CaPDE2 is required for hyphal development in Candida albicans. Microbiology 2003, 149, 2961-2976. [CrossRef] [PubMed]

77. Cloutier, M.; Castilla, R.; Bolduc, N.; Zelada, A.; Martineau, P.; Bouillon, M.; Magee, B.B.; Passeron, S.; Giasson, L.; Cantore, M.L. The two isoforms of the cAMP-dependent protein kinase catalytic subunit are involved in the control of dimorphism in the human fungal pathogen Candida albicans. Fungal Genet. Biol. 2003, 38, 133-141. [CrossRef]

78. Giacometti, R.; Kronberg, F.; Biondi, R.M.; Passeron, S. Candida albicans Tpk1p and Tpk2p isoforms differentially regulate pseudohyphal development, biofilm structure, cell aggregation and adhesins expression. Yeast 2011, 28, 293-308. [CrossRef] [PubMed]

79. Giacometti, R.; Kronberg, F.; Biondi, R.M.; Passeron, S. Catalytic isoforms Tpk1 and Tpk2 of Candida albicans PKA have non-redundant roles in stress response and glycogen storage. Yeast 2009, 26, 273-285. [CrossRef] [PubMed]

80. Slutsky, B.; Staebell, M.; Anderson, J.; Risen, L.; Pfaller, M.; Soll, D.R. “White-opaque transition": A second high-frequency switching system in Candida albicans. J. Bacteriol. 1987, 169, 189-197. [CrossRef] [PubMed]

81. Soll, D.R. Why does Candida albicans switch? FEMS Yeast Res. 2009, 9, 973-989. [CrossRef] [PubMed]

82. Porman, A.M.; Alby, K.; Hirakawa, M.P.; Bennett, R.J. Discovery of a phenotypic switch regulating sexual mating in the opportunistic fungal pathogen Candida tropicalis. Proc. Natl. Acad. Sci. USA 2011, 108, 21158-21163. [CrossRef] [PubMed]

83. Lohse, M.B.; Johnson, A.D. White-opaque switching in Candida albicans. Curr. Opin. Microbiol. 2009, 12, 650-654. [CrossRef] [PubMed]

84. Anderson, J.M.; Soll, D.R. Unique phenotype of opaque cells in the white-opaque transition of Candida albicans. J. Bacteriol. 1987, 169, 5579-5588. [CrossRef] [PubMed]

85. Tong, Y.; Cao, C.; Xie, J.; Ni, J.; Guan, G.; Tao, L.; Zhang, L.; Huang, G. N-acetylglucosamine-induced white-to-opaque switching in Candida albicans is independent of the Wor2 transcription factor. Fungal Genet. Biol. 2014, 62, 71-77. [CrossRef] [PubMed]

86. Liu, Z.H.; Li, M.; Lu, X.L.; She, X.D.; Hu, S.Q.; Chen, W.; Liu, W.D. Higher concentration of $\mathrm{CO}_{2}$ and 37 degrees $C$ stabilize the less virulent opaque cell of Candida albicans. Chin. Med. J. 2010, 123, 2446-2450. [PubMed]

87. Huang, G.; Srikantha, T.; Sahni, N.; Yi, S.; Soll, D.R. $\mathrm{CO}_{2}$ regulates white-to-opaque switching in Candida albicans. Curr. Biol. 2009, 19, 330-334. [CrossRef] [PubMed]

88. Huang, G.; Yi, S.; Sahni, N.; Daniels, K.J.; Srikantha, T.; Soll, D.R. N-acetylglucosamine induces white to opaque switching, a mating prerequisite in Candida albicans. PLoS Pathog. 2010, 6, e1000806. [CrossRef]

89. Grahl, N.; Demers, E.G.; Lindsay, A.K.; Harty, C.E.; Willger, S.D.; Piispanen, A.E.; Hogan, D.A. Mitochondrial Activity and Cyr1 Are Key Regulators of Ras1 Activation of C. albicans Virulence Pathways. PLoS Pathog. 2015, 11, e1005133. [CrossRef] [PubMed]

90. Shapiro, R.S.; Zaas, A.K.; Betancourt-Quiroz, M.; Perfect, J.R.; Cowen, L.E. The Hsp90 co-chaperone Sgt1 governs Candida albicans morphogenesis and drug resistance. PLoS ONE 2012, 7, e44734. [CrossRef] [PubMed]

91. Xie, J.L.; O'Meara, T.R.; Polvi, E.J.; Robbins, N.; Cowen, L.E. Staurosporine Induces Filamentation in the Human Fungal Pathogen Candida albicans via Signaling through Cyr1 and Protein Kinase A. mSphere 2017. [CrossRef] [PubMed]

92. Hornby, J.M.; Jensen, E.C.; Lisec, A.D.; Tasto, J.J.; Jahnke, B.; Shoemaker, R.; Dussault, P.; Nickerson, K.W. Quorum sensing in the dimorphic fungus Candida albicans is mediated by farnesol. Appl. Environ. Microbiol. 2001, 67, 2982-2992. [CrossRef] [PubMed]

93. Schrevens, S.; Van Zeebroeck, G.; Riedelberger, M.; Tournu, H.; Kuchler, K.; Van Dijck, P. Methionine is required for cAMP-PKA-mediated morphogenesis and virulence of Candida albicans. Mol. Microbiol. 2018. [CrossRef] [PubMed]

94. Steinbach, W.J.; Reedy, J.L.; Cramer, R.A., Jr.; Perfect, J.R.; Heitman, J. Harnessing calcineurin as a novel anti-infective agent against invasive fungal infections. Nat. Rev. Microbiol. 2007, 5, 418-430. [CrossRef] [PubMed] 
95. Kontoyiannis, D.P.; Lewis, R.E.; Alexander, B.D.; Lortholary, O.; Dromer, F.; Gupta, K.L.; John, G.T.; Del Busto, R.; Klintmalm, G.B.; Somani, J.; et al. Calcineurin inhibitor agents interact synergistically with antifungal agents in vitro against Cryptococcus neoformans isolates: Correlation with outcome in solid organ transplant recipients with cryptococcosis. Antimicrob. Agents Chemother. 2008, 52, 735-738. [CrossRef] [PubMed]

96. Singh, N.; Alexander, B.D.; Lortholary, O.; Dromer, F.; Gupta, K.L.; John, G.T.; del Busto, R.; Klintmalm, G.B.; Somani, J.; Lyon, G.M.; et al. Cryptococcus neoformans in organ transplant recipients: Impact of calcineurininhibitor agents on mortality. J. Infect. Dis. 2007, 195, 756-764. [CrossRef] [PubMed]

(C) 2018 by the authors. Licensee MDPI, Basel, Switzerland. This article is an open access article distributed under the terms and conditions of the Creative Commons Attribution (CC BY) license (http:/ / creativecommons.org/licenses/by/4.0/). 